\title{
Mental health and the experience of housing problems involving rights ${ }^{1}$
}

\author{
Pascoe Pleasence* and Nigel Balmer \\ University College London
}

\begin{abstract}
The incidence of housing problems involving rights is linked closely to long-term illness/disability and broader social exclusion. In this paper we draw on data from the English and Welsh Civil and Social Justice Survey to explore the extent to which housing rights problems and mental illness co-occur, and the causal connections between them.

After controlling for a range of social and demographic predictors, we find significant associations between housing rights problems and mental illness. We also find that housing rights problems are often reported to lead to stress related illness. We argue that effective co-ordination of mental health and housing rights advice services is likely to improve both health and justice outcomes.
\end{abstract}

Keywords: mental health, mental illness, rights, rights problems, legal problems.

\section{Introduction}

A broad range of housing problems involve people's legal rights or responsibilities. For example, homelessness, or the threat of homelessness, can give rise to rights under Part VII of the Housing Act 1996, as amended by the Priority Needs Order 2001 and the Homelessness Act 2002. Tenants have rights with regard to the maintenance of their home under, for instance, the Landlord and Tenant Act 1985 and Housing Act 2004. Tenants also have rights concerning eviction under a range of statutory and common law provisions, such as the Rent Act 1977, the Protection from Eviction Act 1977, the Housing Act 1985 and Housing Act 1988. Similarly, they have rights around the holding of deposits under the Housing Act 2004. Anti-social behaviour on the part of neighbours may also involve rights under, for example, the general law of nuisance, the Environmental Protection Act 1990, the Noise Act 1996, the Protection from Harassment Act 1997 and the Anti-Social Behaviour Act 2003. 
Of course, the fact that problems involve people's rights or responsibilities does not mean that they must, or even should, be resolved by recourse to law. It means only that legal processes provide one potential means through which they might be resolved and that the law provides a reference against which they can potentially be resolved more generally - in the 'shadow of the law' (Mnookin and Kornhauser, 1979). Whether legal processes are used is a matter of appropriateness, as well as knowledge and capacity. As Lewis (1973) famously observed, a tenant with a leaking roof may need a ladder more than a lawyer. Rights problems, as experienced by the public, have thus been described as 'justiciable', rather than legal (Genn, 1999).

We have shown previously that the incidence of housing rights problems in England and Wales is linked to long-term illness/disability (Pleasence et al., 2004a). Similar findings have also been reported in a number of other jurisdictions, including Northern Ireland (Dignan, 2006), Canada (Currie, 2007) and Australia (Coumarelos et al., 2006). We have also shown that people attribute both stress-related and physical ill health to such problems (Pleasence et al., 2007). In the case of mental illness, the implications of links with housing rights problems may be particularly pronounced. Common forms of mental illness may affect up to 1 in 6 people in the United Kingdom at any given time (Singleton et al., 2001) and such illness is enduring for many (Singleton and Lewis, 2003). It has been estimated that the annual cost of mental illness to the United Kingdom is over $£ 77$ billion (US\$151 billion) (Sainsbury Centre for Mental Health, 2003).

To the extent that housing rights problems play a role in bringing about or exacerbating mental illness, there is a role for housing rights advice services in its reduction. To the extent that mental illness plays a role in bringing about or exacerbating rights problems, advice services must accommodate this and reflect the particular needs of people facing mental illness.

As with ill health more generally, there is increasing evidence of a relationship between housing rights problems and mental health. For example, In the United Kingdom, it has been stated that one in four tenants with mental health problems has serious rent arrears and is at risk of losing their home (Social Exclusion Unit, 2004). Losing one's home can also act to bring about mental health problems (Nettleton and Burrows, 2000). Thus, homelessness is associated with high levels of mental illness (Gill et al., 1996; Hodder et al., 1998; Commander et al., 2002; Griffiths, 2002; British Medical Association, 2003; Warnes et al., 2003; Mental Health Foundation, 2006). This is on top of people with mental illness being frequently 'relegated' to poor quality and delapidated housing (Meltzer et al., 2002; British Medical Association, 2003; Fryers et al., 2005). Poor quality housing has also been suggested as a contributor to psychological problems (Davis, 2003; Fryers et al., 2005; Wells and Harris, 2007). People facing mental health problems have also been shown to be more vulnerable than others to anti-social behaviour on the part of neighbours (Read and Baker, 1996; Berzins et al., 2003; Hunter et al., 2007), apparently in part in consequence of their relegation to areas of poor quality housing. As Kelly and McKenna (1997, at p.190) have observed, many people with enduring mental illness are 'accommodated in what would be termed 'difficult to let' accommodation.'

However, there is still some uncertainty as to the nature of some of the associations set out above, and the path and direction of causation is sometimes opaque. This may be because causation is frequently bidirectional. It has often been suggested that social problems - which include rights problems - and mental illness may mutually reinforce each other in a vicious cycle (Social Exclusion Unit, 2004).

In this paper we draw upon new data from the English and Welsh Civil and Social Justice Survey to explore further the relationship between housing rights problems and 
mental illness. In doing so, we also re-examine the frequency with which stress-related illness is attributed as a cause or a consequence of such problems. Finally, we discuss the role of housing advice services in the prevention and mitigation of mental illness.

It is hypothesised that respondents who report housing rights problems will be more likely to report mental illness than those who do not report such problems. It is also hypothesised that the experience of problems will be cited as a cause of mental illness.

\section{Methods}

\section{English and Welsh Civil and Social Justice Survey: An Introduction}

The English and Welsh Civil and Social Justice Survey (CSJS) collects detailed information on the nature, pattern and impact of people's experiences of rights problems. It was first conducted in 2001, then in 2004 and, since 2006, has been conducted on a continuous basis (meaning that fieldwork is now conducted every month of every year). The purpose of the CSJS is to provide a broad empirical base for civil justice policy development and to allow the impact of government policies to be assessed and progress against Public Service Agreement (PSA) targets to be measured.

In terms of detail, the CSJS is the most extensive survey of its kind so far undertaken. It has its origins in a tradition of surveys dating back to the recession at the United States' Bar in the 1930s (Clark and Corstvet, 1938), though the nature and form of the questionnaires used can be most easily traced to Genn's (1999) Paths to Justice surveys.

In confirming that rights problems are concentrated among the most vulnerable members of society, establishing how they contribute to social exclusion (Buck et al., 2005), ascertaining the extent to which rights problems 'cluster' (Pleasence et al., 2004 b) and exposing the problems that people face in obtaining advice (Pleasence et al., 2004a), the CSJS has had a profound effect on policy in the area of access to justice - most recently in supporting moves to procure legal aid services in 'bundles that recognise the multiple nature of clients' problems' through the development of Community Legal Advice Centres and Networks (Legal Services Commission, 2006: 7). In the same vein, the CSJS has regularly been used to demonstrate the need for effective integration of public services aimed at addressing social exclusion. To this end, an increasing amount of data is being collected on issues such as mental health, which is at the centre of the UK government's strategy on social exclusion (HM Treasury, 2007).

\section{English and Welsh Civil and Social Justice Survey: The Study Data}

All respondents to the CSJS complete a general interview, in which they are asked whether they have experienced 'a problem', within the preceding three years, that has been 'difficult to solve' in each of 99 categories of rights problems, grouped into 18 broader categories for the purposes of interview. The 99 categories include 27 housing related categories, which are detailed in Table 1, along with the incidence of such problems as reported through the survey. Housing rights problems are grouped into 4 broad categories: anti-social neighbours, rented housing, owned housing and homelessness. Respondents are also asked for details about themselves and their household. 
p. 7. Mental health and the experience of housing problems involving rights

Table 1: Percentage of respondents reporting housing rights problems

\begin{tabular}{|c|c|c|c|}
\hline $\begin{array}{l}\text { Problem type } \\
\text { Any housing }\end{array}$ & Sub-category & $\begin{array}{l}\mathrm{N} \\
336\end{array}$ & $\begin{array}{l}\% \\
12.8\end{array}$ \\
\hline \multirow[t]{6}{*}{ Neighbours } & Overall & 201 & 7.7 \\
\hline & Regular and excessive noise & 128 & 4.9 \\
\hline & Threats or harassment & 41 & 1.6 \\
\hline & Violence & 18 & 0.7 \\
\hline & Damage to your property or garden & 69 & 2.6 \\
\hline & Other vandalism & 29 & 1.1 \\
\hline \multirow[t]{8}{*}{ Owned housing } & Overall & 51 & 2.0 \\
\hline & Planning permission or consent & 12 & 0.5 \\
\hline & Selling or buying property (e.g. misleading survey) & 13 & 0.5 \\
\hline & Communal repairs or maintenance & 9 & 0.3 \\
\hline & Repossession of the home & 0 & 0.0 \\
\hline & Having several mortgage payments in arrears & 1 & 0.0 \\
\hline & Dealing with squatters & 2 & 0.1 \\
\hline & Boundaries or rights of way or access to your property & 17 & 0.6 \\
\hline \multirow[t]{19}{*}{ Rented housing } & Overall & 73 & 2.8 \\
\hline & Condition of accommodation (overall) & 16 & 0.6 \\
\hline & Unsafe living conditions & 12 & 0.5 \\
\hline & Otherwise unsuitable conditions for yourself/family & 7 & 0.3 \\
\hline & Problems to do with money (overall) & 14 & 0.5 \\
\hline & Getting a deposit back & 12 & 0.4 \\
\hline & Being several rent payments in arrears & 2 & 0.1 \\
\hline & Dealing with landlord (overall) & 48 & 1.8 \\
\hline & Getting the property repaired or maintained & 41 & 1.6 \\
\hline & Provision of other services under lease (e.g. furniture) & 2 & 0.1 \\
\hline & Disagreement on other terms of lease / agreement & 4 & 0.2 \\
\hline & Obtaining a written lease or tenancy agreement & 2 & 0.1 \\
\hline & Transfer of tenancy on death or separation & 0 & 0.0 \\
\hline & Harassment by your landlord & 1 & 0.0 \\
\hline & Eviction or threat of eviction & 6 & 0.2 \\
\hline & Other problems (overall) & 6 & 0.2 \\
\hline & Flatmates not paying the rent or anti-social behaviour & 4 & 0.1 \\
\hline & Renting out rooms to lodgers / sub-letting & 0 & 0.0 \\
\hline & Boundaries or rights of way or access to your property & 2 & 0.1 \\
\hline Homelessness & Overall & 34 & 1.3 \\
\hline
\end{tabular}

In relation to health, all respondents are asked whether they have had 'a longstanding illness, disability or infirmity ... that troubled [them] over a period of time or that was likely to affect [them] over a period of time' within the past three years. They are also asked whether they have 'suffered from stress, depression or some other kind of mental health problem' within the past three years. For those who say they have, a follow-up question is then asked, which seeks to identify whether respondents obtain medical treatment as a result. Those that have are asked for details of the type of illness suffered. Respondents are also asked about the negative consequences of rights problems, including 'stress related illness'. Finally, for one (randomly selected) problem, respondents are asked whether any stress related illness led to use being made of health services. 


\section{p. 8. Mental health and the experience of housing problems involving rights}

All interviews for the continuous CSJS are conducted in respondents' own homes. Mean interview duration is around half an hour. 2,628 adults, aged 18 or over, were included in the period of the CSJS used within this study (July 2006 - March 2007), drawn from a random selection of 1,566 households across England and Wales. The household response rate was 67 per cent, and the cumulative eligible adult response rate was 48 per cent.

\section{Analysis}

First, we undertook a simple descriptive analysis of the incidence of housing rights problems and long-term illness/disability and mental illness. We then fitted a multilevel binary logistic regression model ${ }^{2}$, implemented using MIwiN (Rasbash et al., 2004 ), to test the influence of illness/disability and a range of further social and demographic predictors upon the likelihood of respondents having experienced a housing problem. The illness/disability predictor comprised four categories: 'mental illness alone', 'both mental illness and long-term illness/disability', 'long-term illness/disability reported, but no mental illness' and 'no mental illness or long-term illness/disability'. The full set of predictors used was: illness/disability status, gender, ethnicity, house type, tenure type, family type, use of mechanised transport, economic status, benefits status, qualifications, income and crime victimisation. Predictors were entered simultaneously as main effects only. Importantly, those in each illness/disability category were age-standardised using the direct method (Armitage et al., 2002), to account for the known association between illness/disability and age. Age standardisation removed the need to include age as a separate predictor. Standardisation was used in conjunction with a more general weighting for survey nonresponse.

Multilevel binary logistic regression models were also fitted at the level of the four broad housing problem categories, to enable some differences in patterns of experience to be illustrated.

Finally, we undertook simple descriptive analyses to examine the extent to which respondents' mental health was stated to have suffered as a result of problems, and for which types of problem health was most often reported to have suffered.

\section{Results}

\section{Setting the scene: incidence of housing rights problems and mental illness} Thirteen per cent of respondents to the CSJS (336 out of 2,628 repondents) reported one or more housing rights problems, with eight per cent (203) reporting problems with anti-social neighbours, three per cent (68) problems concerning rented housing, two per cent (53) problems with owned housing and one per cent (32) homelessness.

Seventeen per cent of CSJS respondents reported having suffered from stress, depression or some other kind of mental health problem in the preceding three years. Of these, 72 per cent (ten per cent overall) indicated that they had seen a doctor, counsellor or nurse about their mental health problem. Sixty per cent of those who received medical treatment were diagnosed as suffering from depression, with most of the remainder reporting anxiety or panic attacks. Around 3 per cent reported having been diagnosed as bipolar.

Separately, 26 per cent of CSJS respondents reported having suffered from a longterm illness or disability at some point during the three-year survey reference period. In 


\section{p. 9. Mental health and the experience of housing problems involving rights}

all, 36 per cent of respondents reported either mental illness or long-term illness or disability in the three years. Forty-one per cent of those who reported having suffered a mental illness also reported a long-term illness or disability. Thirty-one per cent of respondents who reported suffering a long-term illness or disability also reported having suffered a mental illness.

\section{Relationship between rights problems and mental illness}

Results from our multilevel binary logistic regression analysis of the incidence of housing rights problems showed that CSJS respondents reporting mental illness were more than twice as likely to report one or more such problems than those reporting no illness or disability (see appendix for details). This was particularly so for those who reported both mental illness and a long-term illness or disability, who were three times as likely to report one or more problems than those reporting no illness or disability.

The results indicated no significant difference between the experience of those who reported long-term illness or disability, but no mental illness, and those who reported no long-term illness or disability.

In percentage terms, 26 per cent of all CSJS respondents who reported a mental illness also reported a housing rights problem. This compared to 11 per cent of other respondents. The figure for respondents with a long-term illness or disability was 17 per cent, though this dropped to 12 per cent when those reporting mental illness were excluded. The figure for those reporting both mental illness and long-term illness or disability was 30 per cent. ${ }^{3}$

Figure 1 shows the incidence of housing rights problems across different age groups, by health status. As can be seen, incidence for younger respondents who reported a mental illness was very high, with 55 per cent of those respondents aged between 25 and 34 years old who reported both a mental illness and long-term illness or disability also reporting problems involving rights.

\section{Figure 1: Housing problem incidence by age and illness/disability status}

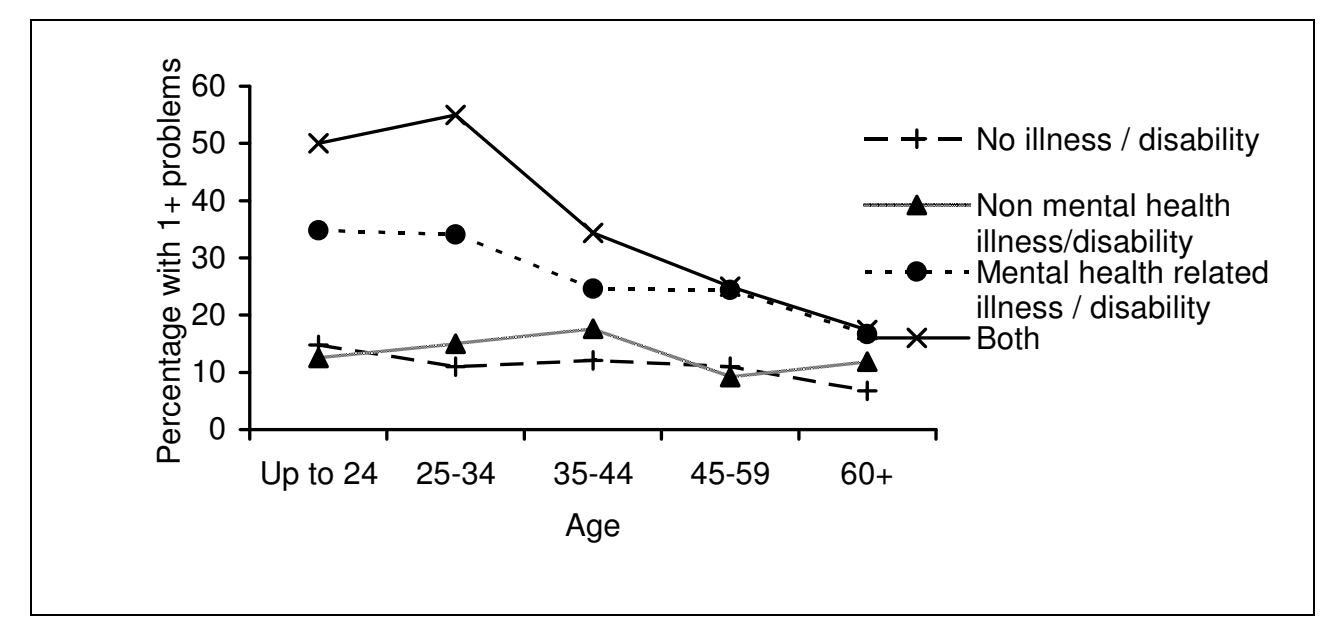

Our analysis of the broad sub-categories of housing rights problem indicated a particular association between homelessness problems and mental illness, though all problem types were significantly associated with mental illness. Homelessness problems were around ten times as likely to be reported by those with a mental illness. ${ }^{4}$ This finding was reflected in the simple frequency of reports of housing rights problems, shown in Figure 2. As can be see, for every problem type, incidence was 


\section{p. 10. Mental health and the experience of housing problems involving rights}

higher among those who reported mental illness than those who reported no illness or disability.

Figure 2: Housing problem incidence by illness/disability status

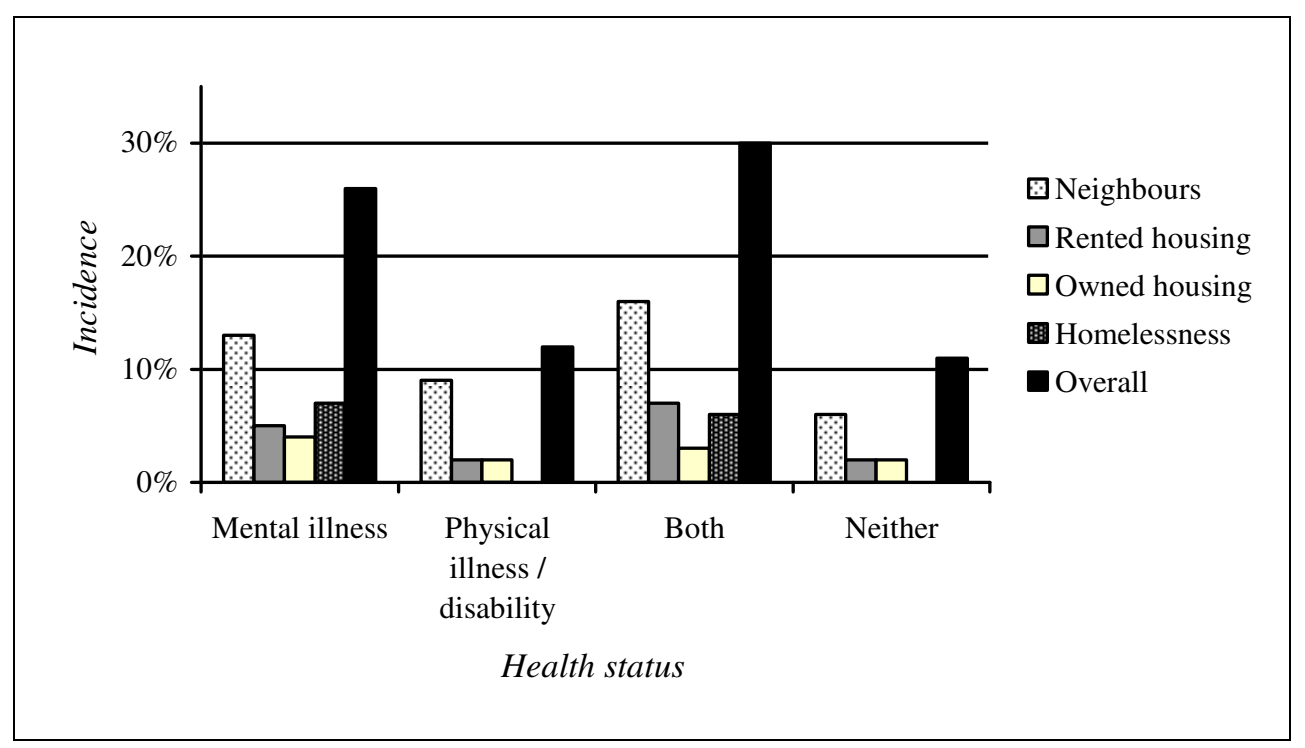

\section{Causes and consequences}

25 per cent of housing rights problems reported through the CSJS were stated to have led to stress related illness. This was most often the case in relation to problems concerning homelessness ( 43 per cent). ${ }^{5}$

Of those people who reported that stress related illness had followed from a problem, 51 per cent went on to receive medical treatment as a result. This was mostly from a GP, but counsellors and community psychiatric nurses were also mentioned frequently.

Of those reporting problems that led to stress related ill health, 72 per cent also reported mental illness more generally. This compared to 24 per cent where stress related ill health was not attributed to problems. Mental illness and the experience of problems leading to stress were clearly connected. One possibility this raises is that housing rights problems may play a part in bringing about mental illness. However, this is not necessarily the case. Mental illness may, for example, increase the likelihood of problems becoming stressful.

\section{Discussion}

\section{Findings and hypotheses}

As hypothesised, our findings provide further evidence of a significant and strong association between housing rights problems and mental illness, particularly in the case of homelessness problems. In fact, particularly for young people, the association between housing rights problems and mental illness, whether experienced in isolation or in combination with physical impairment, appears greater than that between such problems and physical impairment on its own.

Flowing from this, the percentage incidence of housing rights problems (again particularly homelessness problems) was much higher for those reporting a mental 


\section{p. 11. Mental health and the experience of housing problems involving rights}

illness than those reporting no impairment of any type. It was highest for those reporting both mental illness and physical impairment. In this case incidence was three times as high as in the case of those reporting no impairment of any type, and twelve times as high in the case of homelessness problems.

In terms of cause and effect, our findings also indicate that people frequently attribute mental illness - in the form of stress related illness - to housing rights problems. All broad types of problem were reported to have led on occasion to stress related illness.

\section{Limitations}

While the findings set out above are striking, the CSJS did not employ a standard mental health index to identify mental illness during the period that the study data relates to. In light of these findings, the GHQ12 index has now been added, and we will report on this in due course. Neither was the CSJS designed with a focus on mental illness in mind. Nevertheless, incidence of mental illness within the CSJS is in line with United Kingdom estimates. Of course, mental illness reported through the CSJS may not be of a kind that would ordinarily be recognised medically. Prior to being asked about their health, respondents will have already been put in mind of problems that led to stress. However, the fact that 72 per cent of CSJS respondents who reported mental illness also reported having obtained medical treatment as a result provides reassurance that mental health problems would generally have been of a kind that would have been medically recognised. Though, again, even this does not ensure that this was always the case.

Also, high incidence of rights problems among people with a mental illness may not directly compare to incidence more generally. Such people may simply more often find problems 'difficult to solve'.

\section{Implications}

That stress related illness should be associated with, and attributed to, the experience of housing rights problems is unsurprising. Such problems go to the heart of people's lives and functioning. As is evident from the model output presented in the appendix and from earlier findings (Buck et al., 2005), such problems are also linked to other factors of 'social exclusion', thus providing further evidence of the clustering of social, rights and health problems and underlining the MIND (2002) observation that 'stressful life events are more common in socially disadvantaged groups and contribute to the raised prevalence of stress-related mental and physical illness.'

The findings above also provide compelling evidence that housing rights problems are not only associated with mental illness, but may have a role in bringing about and exacerbating mental illness. Given the public cost of mental illness (Sainsbury Centre for Mental Health, 2003), the prevention, amelioration and resolution of rights problems should therefore be a real concern for mental health policy.

In addition, Davis (2003) has stressed the importance of preventing problems brought about by mental illness that can feed a downward spiral of problems. At the heart of this is the need to raise awareness of the reality of mental illness and provide guidance on forms of inclusive practice to those whose work impacts on people with mental illness (Cullen et al., 2004).

Whatever the causal role played by housing rights problems in mental illness, then, it is evident that both need to be treated not in isolation, but in the context of the evident links between them. This requires the co-ordination of information, advice and support services. Beyond this, Nixon's (2007) observation that the 'complex multilayered material reality' of problems concerning anti-social behaviour involves those 
accused of being 'victims' of such behaviour also being sometimes the perpetrators of such behaviour', co-ordination with policing and neighbourhood organisations could also be added to this.

There are growing numbers of examples of co-ordinated and co-located health and advice services (Social Exclusion Unit, 2004b; Noone, 2007), but it is evident that such co-ordination and co-location is not always easy to bring about and 'does not always work well' (Frye and Webb, 2002; Cullen et al., 2004). This is especially so in a context of constantly evolving policy and competing objectives (Banks, 2002; Frye and Webb, 2002), and even more so in a context of limited resources. As Huxham (1996) has observed, 'effective collaboration is highly resource intensive.' It requires time, commitment and trust (Fitch et al., 2007). That does not, though, lessen the value of attempting to 'actively change the landscape' of services in order to improve their effectiveness (Legal Services Commission, 2002; Griffith, 2002), though the costeffectiveness of co-ordination is a factor that must always be borne in mind.

Given the difficulty that people with a mental illness can face in accessing services - linked to retreating behaviour, fear of disclosure, real and perceived communication problems, and other capability issues (Karras et al., 2006; Thornicroft et al., 2007; Rose, 1996; Vasiliou, 2006; Watson et al., 2004) - the role of trust in information, advice and support services for those with mental illness, along with ease of access, is evident. This is an area in which it appears particularly important that advice services should mirror the needs and behaviour of, and reach out to, those who need them.

Related to this, it is evident that people with mental illness require extended support that can act to empower them. There is ample evidence of the importance of enabling people to have influence and control over their lives, so as to bring about 'a sense of self-efficacy or self-confidence in one's ability to achieve desired outcomes' (Davis, 2003, p.20). The experience of those with mental illness of trying to resolve rights problems is a lonely one (Moorhead et al., 2006).

The benefits of effective co-ordination of services and empowerment of those with mental illness to both mental health and justice outcomes would seem readily apparent.

\section{Notes}

1 This article is based on a paper originally presented at the 30th International Academy of Law and Mental Health Congress, Padua, 25th - 30th June 2007.

2 Multilevel modelling (Goldstein, 2003) was used in order to reflect the hierarchical structure of the data. In the CSJS, all eligible adults within households are interviewed, resulting in survey respondents clustered within households.

3 When age standardised, the figure for those reporting long-term illness or disability, but no mental illness, rose to 14 per cent. This is because the incidence of long-term illness and disability increases with age, while incidence of rights problems decreases with age. The figures relating to those who reported a mental illness fell slightly, except in the case of those who also reported a long-term illness or disability, which rose slightly.

${ }^{4}$ For homelessness problems the parameter estimates were 2.43 (0.62 SE), and 2.21 (0.63 SE) for those with a mental illness or both mental illness and long-term illness/disability, respectively, as against those with no illness or disability. The odds ratios associated with these estimates were 11.4 and 9.11 respectively. The corresponding figures for neighbours, rented housing and owned housing problems were 0.43 (0.26 SE), 0.71 (0.27 SE), 0.41 (0.5 SE), 0.77 (0.39 SE), 0.9 (0.44 SE), 0.79 (0.56 SE), respectively.

5 The percentages for problems concerning rented housing, anti-social neighbours and owned housing were 32 per cent, 24 per cent and 10 per cent respectively. 
p. 13. Mental health and the experience of housing problems involving rights

\section{Acknowledgements}

The authors would like to thank Caroline Hunter and Judy Nixon, along with the journal's anonymous reviewers, for their constructive comments on an earlier version of this paper.

* Correspondence Address: Professor Pascoe Pleasence, Faculty of Law, University College London, Bentham House, Endsleigh Square, London, WC1H OEG. Email: p.pleasence@ucl.ac.uk.

\section{References}

Armitage, P., Berry, G., Matthews, J.N.S. (2002) Statistical methods in medical research (4th edition). Oxford: Blackwell.

Banks, P. (2002) Partnerships Under Pressure. London: King's Fund.

Berzins, K.M., Petch, A. and Atkinson, J.M. (2003) Prevalence and Experience of harassment of People with Mental Health Problems Living in the Community. The British Journal of Psychiatry, 183, 526-533.

British Medical Association (2003) Housing and health: building for the future. London: BMA.

Buck, A., Pleasence, P. and Balmer, N.J. (2005) Social Exclusion and Civil Law: Experience of Civil Justice Problems Among Vulnerable Groups. Social Policy and Administration, 39, 3, 302.

Clark, C. and Corstvet, E. (1938) The Lawyer and the Public: An A.A.L.S. Survey. Yale Law Journal, 47, 1972.

Commander, M., Davis, A., McCabe, A. and Stanyer, A. (2002) A comparison of homeless and domiciled young people. Journal of Mental Health 11, 5, 557-564.

Cullen, L., Edwards, S., Marks, S., Phelps, L., Sandbach, J. (2004) Out of the Picture: $C A B$ Evidence on Mental Health and Social Exclusion. London: Citizens Advice.

Currie, A. (2007) Civil Justice Problems and the Disability and Health Status of Canadians, in: Pleasence, P., Buck, A. and Balmer N.J. (eds.) Transforming Lives: Law and Social Process. Norwich: TSO.

Coumarelos, C., Wei, Z. and Zhou, A. (2006) Justice Made to Measure: NSW Legal Needs Survey in Disadvantaged Areas. Sydney: Law and Justice Foundation of NSW.

Davis, A. (2003) Mental Health and Personal Finances: A Literature Review. Birmingham: University of Birmingham.

Dignan, T. (2006) Northern Ireland Legal Needs Survey. Belfast: Northern Ireland Legal Services Commission.

Fitch, C., Simpson, A., Collard, S. and Teasdale, M. (2007) Mental Health and Debt: Challenges for Knowledge, Practice and Identity. Journal of Psychiatric and Mental Health Nursing, 14, 2, 128-133.

Frye, M. and Webb, A. (2002) Working Together: Effective Partnership Working on the Ground. London: HM Treasury.

Fryers, T., Melzer, D., Jenkins, R. and Brugha, T. (2005) The Distribution of Common Mental Disorders: Social Inequalities in Europe. Clinical Practice and Epidemiology in mental Health, 1, 14.

Gill, B., Meltzer, H., Hinds, K. and Petticrew, M. (1996) Psychiatric Morbidity among Homeless People. London: TSO.

Goldstein, H. (2003) Multilevel statistical models (3rd edition). London: Arnold.

Griffith, A. (2002) Partnerships and the Community Legal Service: A Discussion Paper. London: Advice Services Alliance. 
Griffiths, S. (2002) Addressing the Health Needs of Rough Sleepers. London: Office of the Deputy Prime Minister.

HM Treasury (2007) PSA Delivery Agreement 16: Increase the Proportion of Socially Excluded Adults in Settled Accommodation and Employment, Education or Training. London: HM Treasury.

Hodder, T., Teesson, M. and Buhrich, N. (1998) Down and Out in Sydney: Prevalence of Mental Disorders, Disability and Health Service Use among Homeless People in Inner Sydney. Sydney: Sydney City Mission.

Hunter, C., Hodge, N., Nixon, J., Parr, S. and Willis, B. (2007) Disabled People's Experiences of Anti-Social Behaviour and Harassment in Social Housing: A Critical Review. London: Disability Rights Commission.

Huxham, C. (1996) Advantage or Inertia? Making Collaboration Work, in: R. Paton, G. Clark, G. Jones, J.M. Lewis and P. Quintas (eds.) The New Management Reader, London: Routledge.

Ignite Research (2006) Report on the 2006 National Survey of Unmet Legal Needs and Access to Services. Wellington: Legal Services Agency.

Karras, M., McCarron, E., Gray, A. and Ardasinski, S. (2006) On the Edge of Justice: The Legal Needs of People with a Mental IIIness in New South Wales. Sydney: Law and Justice Foundation of New South Wales.

Kelly, L.S. and McKenna H.P. (1997) Victimization of People with Enduring Mental Illness in the Community. Journal of Psychiatric and Mental Health Nursing, 4, 185-191.

Legal Services Commission (2002) Post-Implementation Review of the Community Legal Service. London: Legal Services Commission.

Legal Services Commission (2006) Making Legal Rights a Reality: the Legal Services Commission's Strategy for the Community Legal Service. London: Legal Services Commission.

Lewis, P. (1973) Unmet Legal Needs, in: P. Morris, R. White and P. Lewis (eds.) Social Needs and Legal Action. Oxford: Martin Robertson.

Meltzer, H., Singleton, N., Lee, A., Bebbington, P., Brugha, T. and Jenkins, R. (2002) The Social and Economic Circumstances of Adults with Mental Disorders. London: TSO.

Mental Health Foundation (2006) Making the Link between Mental Health and Youth Homelessness: A Pan-London Study. London: Mental Health Foundation.

MIND (2002) Factsheet: The Social Context of Mental Distress. London: MIND

Mnookin, R.H. and Kornhauser, L. (1979) Bargaining in the Shadow of the Law: The Case of Divorce. 88 Yale Law Journal 950.

Moorhead, R, Robinson, M. and Matrix Research and Consultancy (2006) A Trouble Shared: Legal Problems Clusters in Solicitors' and Advice Agencies. London: Department for Constitutional Affairs.

Nettleton, S. and Burrows, R. (2000) When a capital investment becomes an emotional loss: the health consequences of the experience of mortgage possession in England. Housing Studies, 15, 463.

Nixon, J. (2007) The Anti-Social Subject - Mad, Bad and Dangerous to Know? Paper presented at the $30^{\text {th }}$ International Academy of Law and Mental Health Congress, Padua, June $25^{\text {th }}-30^{\text {th }}$.

Noone, M.A. (2007) 'They All Come In One Door' The Transformative Potential of an Integrated Service Model: A Study of the West Heidelberg Community Legal Service, in: Pleasence, P., Buck, A. and Balmer, N.J. (eds.) Transforming Lives: Law and Social Process. Norwich: TSO.

Pleasence, P., Balmer, N.J., Buck, A., O'Grady, A. and Genn, H. (2004a) Civil law problems and morbidity. Journal of Epidemiology and Community Health, 58, 552. 
Pleasence, P., Balmer, N.J., Buck, A., O'Grady, A. and Genn, H. (2004b) Multiple Justiciable Problems: Common Clusters, Problem Order and Social and Demographic Indicators. Journal of Empirical Legal Studies, 1, 2, 301.

Pleasence, P., Balmer, N.J., Buck, A., Smith, M. and Patel, A. (2007) Mounting Problems: Further Evidence of the Social, Economic and Health Consequences of Civil Justice Problems in: Pleasence, P., Buck, A. and Balmer, N.J. (eds.) Transforming Lives: Law and Social Process. Norwich: TSO.

Rasbash, J., Steele, F., Browne, W. and Prosser, B. (2004) A user's guide to MIwiN (version 2.0). London: Institute of Education.

Read, J. and Baker, S. (1996) Not Just Sticks and Stones: A Survey of Stigma, Taboos and Discrimination Experienced by People with Mental Health Problems. London: MIND.

Rose, D. (1996) Living in the Community, London: Sainsbury Centre for Mental Health.

Sainsbury Centre for Mental Health (2003) Policy Paper 3: The Economic and Social Costs of Mental IIIness. London: Sainsbury Centre for Mental Health.

Singleton, N., Bumpstead, R., O'Brian, M., Lee, A. and Meltzer, H. (2001) Psychiatric Morbidity Among Adults Living in Private Households. London: TSO.

Singleton, N. and Lewis, G. (2003) Better or Worse: A Longitudinal Study of the Mental Health of Adults Living in Private Households in Great Britain. London: TSO.

Social Exclusion Unit (2001) Preventing Social Exclusion. London: Cabinet Office

Social Exclusion Unit (2004) Mental Health and Social Exclusion. London: Office of the Deputy Prime Minister.

Social Exclusion Unit (2004b) Action on Mental Health: A Guide to Promoting Social Inclusion. London: Office of the Deputy Prime Minister.

Thornicroft, G., Rose, D., Kassam, A and Sartorius (2007) Stigma: Ignorance, Prejudice or Discrimination? British Journal of Psychiatry, 190, 192-193.

Vasiliou, C. (2006) Making the Link between Mental Health and Youth Homelessness: A Pan-London Study. London: Mental Health Foundation.

Warnes, A., Crane, M., Whitehead, N. and Fu, R. (2003) Homelessness Factfile. London: Crisis.

Watson, A.C., Corrigan, P.W. and Ottati, V. (2004) Police Responses to Persons with Mental Illness: Does the Label Matter? Journal of the American Academy of Psychiatry and the Law, 32, 378-385.

Wells, N.M. and Harris, J.D. (2007) Housing Quality, Psychological Distress, and the mediating Role of Social Withdrawal: A Longitudinal Study of Low-Income Women. Journal of Environmental Psychology, 27, 1, 69-78. 
p. 16. Mental health and the experience of housing problems involving rights

\section{Appendix}

Parameter estimates (and standard errors) for multilevel models of incidence of one or more housing rights problem.

\begin{tabular}{|c|c|c|c|}
\hline \multirow[t]{2}{*}{ Covariate } & \multirow[t]{2}{*}{ Levels } & \multicolumn{2}{|c|}{ Any problem } \\
\hline & & Est. & SE \\
\hline Constant & & -3.65 & 0.41 \\
\hline \multirow[t]{5}{*}{ Illness/disability } & None & - & - \\
\hline & Mental illness only & 0.75 & 0.21 \\
\hline & No mental illness, but long-term & & \\
\hline & illness/disability & 0.14 & 0.22 \\
\hline & Both & 1.11 & 0.22 \\
\hline \multirow[t]{2}{*}{ Gender } & Female & - & - \\
\hline & Male & -0.21 & 0.13 \\
\hline \multirow[t]{4}{*}{ Ethnicity } & White & - & - \\
\hline & Black & -0.46 & 0.64 \\
\hline & Asian & -0.83 & 0.46 \\
\hline & Other & -0.01 & 0.54 \\
\hline \multirow[t]{4}{*}{ House type } & Detached & - & - \\
\hline & Semi-detached & 0.12 & 0.24 \\
\hline & Terrace & 0.47 & 0.25 \\
\hline & Flat & 1.04 & 0.29 \\
\hline \multirow[t]{2}{*}{ Use of transport } & No & - & - \\
\hline & Yes & 0.36 & 0.21 \\
\hline \multirow[t]{6}{*}{ Family type } & Married, children & - & - \\
\hline & Married no children & 0.15 & 0.25 \\
\hline & Lone parent & -0.03 & 0.35 \\
\hline & Single no children & 0.15 & 0.28 \\
\hline & Cohabiting, children & 0.81 & 0.42 \\
\hline & Cohabiting no children & 0.38 & 0.37 \\
\hline \multirow[t]{5}{*}{ Tenure } & Own & - & - \\
\hline & Mortgage & -0.33 & 0.23 \\
\hline & Rent publicly & 0.70 & 0.24 \\
\hline & Rent privately & 0.50 & 0.25 \\
\hline & Rent free & -0.23 & 0.44 \\
\hline \multirow[t]{2}{*}{ Economic activity } & Active & - & - \\
\hline & Inactive & 0.24 & 0.18 \\
\hline \multirow[t]{2}{*}{ Academic qualifications } & No & - & - \\
\hline & Yes & 0.42 & 0.18 \\
\hline \multirow[t]{2}{*}{ Receipt of welfare benefits } & No & - & - \\
\hline & Yes & 0.48 & 0.19 \\
\hline \multirow[t]{3}{*}{ Household/personal income } & All others & & \\
\hline & $<£ 10,000$ & -0.42 & 0.18 \\
\hline & $>£ 50,000$ & -0.07 & 0.25 \\
\hline \multirow[t]{2}{*}{ Victim of Crime } & No & - & - \\
\hline & Yes & 0.91 & 0.17 \\
\hline Between household variance & & 1.47 & 0.41 \\
\hline
\end{tabular}

Figures in bold: $p<0.05$. 